\title{
TARIAN MA'ATENU DI PULAU HARUKU KABUPATEN MALUKU TENGAH
}

\author{
Dance of Ma'atenu in Haruku Island \\ District, Central Maluku Regency
}

\author{
La Sakka \\ Balai Penelitian dan Pengembangan Agama Makassar \\ Jl. AP. Pettarani No. 72 Makassar \\ Email: sakkamuskin@yahoo.com
}

Naskah diterima tanggal 28 Juli 2015. Naskah direvisi tanggal 10 Agustus 2015. Naskah disetujui tanggal 03 November 2015.

\begin{abstract}
Abstrak
Penelitian ini menggunakan pendekatan kualitatif yang berusaha mendeskripsikan proses pelaksanaan Tarian Máatenu di Desa Pelauw ditinjau dari Aqidah Islam. Dalam penelitian ini, menggunakan metode yang lazim digunakan dalam penelian kualitatif yaitu observasi dan wawancara. Hasil penelitian mengungkapkan bahwa Máatenu atau disebut juga cakalele adat adalah ritual perang khas masyarakat Hatuhaha di pulau Haruku Maluku Tengah. Pelaksanaan Upacara tarian Mảatenu dilaksanakan satu kali dalam tiga tahun, dan makna yang terkandung dalam upacara ini adalah makna Agama, makna adat dan makna sosial. Tarian Mảatenu perlu dilestarikan dan dipertahankan keutuhannya sebagai tradisi kesenian yang bernuansa Islam dan perlu diwarisi kepada generasi berikutnya.
\end{abstract}

Kata kunci: tarian, Ma’atenu, upacara

\begin{abstract}
This study used qualitatively descriptive approach to investigate the implementation process of Ma'atenu dance viewed from the Islamic Aqeedah (pilar foundation of Islam) in Pelauw village. The study conducted observation and interview. The findings revealed that Maatenu also called cakalele tradition is the ritual war dance of Hatuhaha people in the Haruku island in central Maluku. Ma'atenu dance ceremony is held once in three years, and its meanings are religion, tradition and social. This dance needs to be preserved and maintained its integrity as a nuanced artistic traditions of Islam and needs to be inherited to the next generations.
\end{abstract}

Keywords: Dance, Ma'atenu, ceremony

\section{PENDAHULUAN}

$\mathrm{M}$ anusia sebagai khalifah Allah yang diciptakan di muka bumi, untuk dapat berintraksi, manusia mempunyai kebaikan dibandingkan dengan makhluk lain, salah satu yang dikaruniai Allah adalah akal budi. Dengan akal budi manusia mampu memikirkan konsepkonsep maupun menyusun prinsip-prinsip hukum yang diikhtiarkan dari berbagai pengamatan dan percobaan.
Dariakal budi, manusia dituntut untuk mampu menciptakan pondasi kehidupannya. Salah satunya adalah budaya sebagai hasil akal budi manusia. Dengan karunia Allah dan akal budi serta cipta rasa dan karsa itulah, manusia mampu menghasilkan berbagai karya dalam bentuk kebudayaan.

Interpretasi seni budaya ketika direfleksikan dalam karya masyarakat pada gilirannya akan menjadi bagian dari adat istiadat dan agama. Karena itu, penggalian nilai-nilai seni budaya dapat mengungkap berbagai segi kearifan lokal, 
seperti kerukunan umat beragama, persaudaraan, perdamaian dan kasih sayang. (Abu Muslim, 2013: 232). Seni budaya sebagai kearifan lokal juga merupakan sarana pembangunan bidang agama yang sejalan dengan Rencana Program Jangka Panjang dan Menengah Nasional (RPJMN) Kementerian Agama 2010-2014, khususnya perwujudan kehidupan sosial yang harmonis, rukun, dan damai di kalangan umat beragama (Atho Mudzhar, 2009: 11-12). Seni meliputi semua bentuk kegiatan tentang aktivitas fisik dan nonfisik yang tertuang dalam kegiatan berekspresi, bereksplorasi, berkreasi dan berapresiasi melalui bahasa rupa, bunyi, gerak dan peran (Rohidi 2000:7). Menurut Joann Kealinohomoku (dalam Sedyawati 1981:26) tari adalah suatu ekspresi yang tak dapat dipegang, yang disajikan dalam bentuk dan gaya tertentu oleh tubuh manusia yang bergerak dalam ruang, berirama, dan mempunyai tujuan tertentu. Soedarsono (1992:4) menjelaskan bahwa tari sebagai ekspresi jiwa manusia dapat dilihat melalui gerakgerak yang indah.

Seni tari merupakan salah satu seni yang menggunakan tubuh manusia sebagai media ungkap. Unsur tari adalah ekspresi gerak dan ekspresi sikap. Lewat unsur-unsur ini tari terbentuk sebagai penyampaian pesan dari pencipta baik secara individu maupun kelompok yang dilakukan oleh sang penari.

Pendapat lain tentang tari menurut Judith (dalam Sulistyowati 1989:11) yakni perilaku manusia yang terdiri atas urutan gerak tubuh dan anggota badan yang nonverbal yang dipolakan secara berirama dan bertujuan sebagai ekspresi yang penuh makna melalui manipulasi gerak secara artistik.

Pembangunan budaya merupakan pilar kunci dalam upaya membangun karakter masyarakat. Pembangunan yang tidak dilandasi dengan pemahaman budaya masyarakat akan sulit mencapai keberhasilan. Karena kebudayaan itu sendiri adalah aspek nilai yang hidup dan tumbuh dalam masyarakat yang menjadi landasan berpikir dan bertingkah laku. Begitu pentingnya pembangunan budaya yang sekaligus menunjukkan keberagaman sebagai bangsa yang kaya dan penuh potensi (Dinas Kebudyaan dan Kepariwisataan Provinsi Sul-Sel, 2012: 1).

Adat merupakan wujud ideal kebudayaan yang sebagai tata kelakuan. Wujud kebudayaan sebagai kompleks aktifitas kelakuan berpola dari manusia dalam masyarakat. Wujud dari kebudayaan yang sering disebut sistem sosial, terdiri dari aktivitas manusia-manusia yang berinteraksi, berhubungan serta bergaul satu dengan yang lain, selalu mengikuti pola-pola tertentu yang berdasarkan adat tata kelakuan.

Adapun penelitian budaya keagamaan yang pernah dilakukan oleh Litbang Agama Makassar adalah: Nilai Keagamaan dalam petuah bijak di Kawasan Timur Indonesia. Penelitian ini mengungkap berbagai jenis petuah bijak berupa pribahasa, pantun, puisi, lagu-lagu Daerah dan karya sastra lainnya. Seperti nilai keagamaan yang terungkap dalam tevai ntotua (ungkapan yang mengandung pesan yang arif dan bijaksana dari leluhur orang Kaili di Palu Sulawesi Tengah). Nabelomo saito kana nabelopa randua, nabelomo randua nalebipa belona nadea. Artinya bila merasa bagus kalau sendiri sesungguhnya lebih bagus jika berdua, sudah bagus berdua akan tetapi lebih bagus lagi kalau banyak orang. Ungkapan ini merupakan sajak persaudaraan yang disampaikan secara turuntemurun oleh masyarakat Kaili. Mereka menekankan betapa pentingnya kebersamaan, kerjasama dan saling tolong menolong dalam menganrungi kehidupan dunia. Hal ini sangat sejalan dengan pesan agama yang senantiasa menganjurkan persaudaraan dan persatuan (Muhammad Sadli Mustafa, 2013: 351-352).

Upacara pelaksanaan Tarian Ma'atenu mempunyai latar belakang yang cukup panjang karena upacara ini sudah berusia ratusan tahun yang dilaksanakan oleh masyarakat Desa Pelauw secara adat.

Acara adat Ma'atenu berlangsung satu hari penuh setiap tiga tahun sekali. Acara adat Tarian Ma'atenu ini berawal dari turunnya masyarakat Amarima Lounusa dari Ama Hatua (Negeri asal di Pegunungan), dimana menggambarkan sejarah perjuangan rakyat Amarima Lounusa melawan penjajah yang dikenal dengan perang Ataka, yang dalam pelaksananya melibatkan seluruh masyarakat Pelauw yang tergolong dalam empat belas unit kelompok solidaritas.

Hal ini menandai adanya suatu hubungan atau ikatan kekerabatan yang paling kuat diantara mereka, baik sesama kelompok kerabat maupun dengan kerabat yang lain di dalam masyarakat. Selain hubungan kekerabatan, tapi mempunyai nilai mistik karena tarian ini biasanya dilakukan dengan memakai senjata tajam berupa parang atau semacamnya. Dan pada tubuh masing-masing biasanya dibekali dengan kekebalan yang didahului 
dengan bacaan-bacaan doa atau ayat-ayat dari Alquran yang diyakini adalah masing-masing anggota (Wawancara A. Aziz Tuasikal).

Berdasarkan pada latar belakang di atas, maka yang menjadi permasalahan pokok dalam penelitian ini adalah: Bagaimna tinjauan aqidah Islam terhadap Tarian Máatenu di Desa Pelauw, selanjutnya dirumuskan beberapa submasalah yakni: Bagaimana proses pelaksanaan Tarian Mảatenu di Desa Pelauw? serta bagaimana pelaksanaan Tarian Ma’atenu ditinjau dari Aqidah Islam?

\section{METODE PENELITIAN}

Penelitian ini merupakan penelitian deskriptif kualitatif yang berusaha menginventarisasi seni keagamaan, serta mendeskripsikan berbagai hal berkaitan dengannya sebagai informasi berharga untuk pengkajian atau pemanfaatan lebih lanjut. Penelitian ini memilih lokasi di Kabupaten Maluku Tengah Propinsi Maluku.

Dalam penelitian ini, digunakan metode yang lazim digunakan dalam penelian kualitatif yaitu observasi dan wawancara. Wawancara dengan informan yang relevan, memiliki informasi berharga tentang penelitian. Informan berasal dari keluarga atau kerabat (sasaran penelitian), tokoh masyarakat, dan anggota masyarakat lainnya.

\section{PEMBAHASAN \\ Setting Penelitian}

Kabupaten Maluku Tengah adalah salah satu kabupaten dari sebelas kabupaten/kota yang ada dalam Propinsi Maluku. Mengingat luasnya propinsi tersebut maka dipilih salah satu kabupaten diantaranya Maluku Tengah. Terkait dengan masalah penelitian yang akan dibahas yaitu Tarian Ma’atenu di Desa Pelauw Kecamatan Pulau Haruku Kabupaten Maluku Tengah, untuk lebih terpokus membahas penelitian ini maka terlebih dahulu digambarkan wilayah sasaran penelitiannya yaitu di Pulau Haruku.

Di antara Pulau Ambon, Pulau Seram, dan Pulau Saparua terdapat satu pulau kecil bernama Pulau Haruku, dengan luas daratannya adalah $150,00 \mathrm{Km}^{2}$. Pulau Haruku ini adalah salah satu kecamatan dari Kabupaten Maluku Tengah. dan di pulau ini terdapat 11 negeri adat, masing-masing: Pelauw, Kailolo, Kabauw, Rohomoni, Samet, Haruku, Oma, Wassu, Aboru, Hulaliu dan Kairu.

Sejak kemerdekaan Republik Indonesia tahun 1945, negeri-negeri di Pulau Haruku dijadikan satu wilayah administratif, berupa kecamatan. Kecamatan Pulau Haruku merupakan satu kecamatan tua di Kabupaten Maluku Tengah. Kecamatan Pulau Haruku terletak pada $1280,42^{\circ}-$

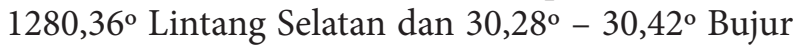
Timur, dengan batas wilayah kecamatan sebagai berikut: sebelah Utara berbatasan dengan Laut Seram, sebelah Selatan berbatasan dengan Laut Banda, sebelah Timur berbatasan dengan Selat Sirsawoni dan sebelah Barat berbatasan dengan Selat Haruku (Kantor Kecamatan Pulau Haruku, 2014)

Pulau Haruku terletak tengada (berhadapan dalam posisi yang lurus) laut Banda. Bepergian ke Pulau Haruku dapat menggunakan jasa trasportasi laut (speedboat) yang tersedia setiap hari dari pagi jam 07.00 sampai sore jam 18.00, atau menggunakan kapal Fery tiga kali seminggu via Tulehu, satu kampung di bagian timur selatan Pulau Ambon. Penyebaran dari pulau Ambon ke Pulau Haruku dapat di tempuh dalam waktu yang relatif singkat (25 s/d 45 menit).

Melihat posisi Pulau Haruku (Kecamatan Pulau Haruku) seperti disebut di atas, tidak mengherangkan bila sejak kemerdekaan Republik Indonesia Kecamatan ini banyak menyuplai sumber daya manusia (SDM) bagi pembangunan bangsa Indonesia, terutama di Maluku. Gubernur pertama Provinsi Maluku, Mr. Yohanes Latuharhary dan sejumlah pejabat birokrat serta dua gubernur lain di belakang, Drs. M. Saleh Latuconsina, Drs. M. Akib Latuconsia berasal dari Kecamatan Pulau Haruku. Saat ini SDM asal Kecamatan Pulau Haruku tersebar hampir pada seluruh wilayah di Maluku dalam tugas selaku birokrasi atau pegawai negeri sipil (PNS), politisi, praktisi, dan pengusaha.

Jumlah penduduk Kecamatan Pulau Haruku sampai tahun 2013 adalah sebanyak 30.519 jiwa, terdiri dari laki-laki15.324 jiwa, dan perempuan 15.195 jiwa, dengan jumlah KK 5.999 KK.

\section{Kehidupan Sosial, Budaya dan Keagamaan Masyarakat}

Kemajuan suatu daerah, antara lain ditentukan oleh kemajuan di bidang pendidikan. Kemajuan dalam bidang pendidikan di Kecamatan Pulau Haruku semakin terasa di dalam masyarakat dengan meningkatnya sarana dan prasarana pendidikan yang dibina oleh pemerintah dan swasta, seperti pembangunan gedung-gedung sekolah, penambahan ruangan kelas, pengangkatan guru, dan perhatian masyarakat terhadap pentingnya pendidikan. 
Pada tahun 2013, di Kecamatan Pulau Haruku terdapat 10 buah Taman kanak-kanak dengan jumlah murid 275 orang, dan dibina oleh 12 orang guru. Jumlah sekolah dasar/madrasah ibtidaiyah sebanyak 28 buah, dengan jumlah murid 3.618 orang dan dibina oleh 296 orang guru. Jumlah SMP/MTs. Sebanyak 10 buah, dengan jumlah murid 2.735 orang, dan dibina oleh 95 orang guru. Jumlah SMA/SMK/MA sebanyak 5 buah, dengan jumlah murid sebanyak 1126 orang, dan dibina oleh 91 orang guru (BPS, 2013).

Di bidang kesehatan, dilaksanakan perbaikan dan peningkatan berbagai sarana dan prasarana kesehatan sesuai kebutuhan. Pada tahun 2013, di Kecamatan Pulau Haruku, walaupun belum memiliki Rumah sakit tetapi sudah memiliki 1 buah Puskesmas dan 7 buah Peskesmas Pembantu dan 17 buah pos Yandu. Pelayanan kesehatan masyarakat dilakukan oleh petugas kesehatan terdiri dokter umum 1 orang, dokter gigi 1 orang apoteker 1orang, perawat 4 orang dan tenaga kesehatan 7 orang.

Sistem kekerabatan di Pulau Haruku menunjuk pada hubungan kekeluargaan, yakni hubungan sosial yang terjadi antara seseorang dengan saudara-saudaranya atau keluarganya, baik dari jalur ayahnya maupun ibunya. Masyarakat Pelauw mengaanut sistem kekeluagaan dari garis keturunan ayah atau orang laki-laki, sehingga garis keturunan bapak menjadi dominan, tetapi mereka sangat menghormati keturunan dari garis ibu atau orang perempuan. A.Tuasical (2014) menyebutkan bahwa; anak cucu dari garis keturunan perempuan mendapat perlakuan khusus dari keluarga garis keturunan ayah. Dalam satu acara yang dihadiri banyak orang misalnya, keturunan dari saudara perempuan yang kawin dengan marga lain diundang dan diberi penghargaan khusus dalam sapaansapaan. Mereka juga dilayani secara khusus dalam acara jamuan makan. Sedangkan dalam kehidupan sehari-hari, bila anak-anak atau keturunan dari orang perempuan dalam marga tertentu datang ke matarumah marga ibu atau neneknya, mereka disambut dengan gembira dan dilayani permintaan atau keperluannya dengan baik. Pola kekeluargaan yang memosisikan garis keturunan ayah dan ibu secara imbang memengaruhi sistem kekerabatan di negeri Pelauw. Sama seperti negeri-negeri lain di Maluku Tengah, penanda kekerabatan di Pelauw adalah marga. Satu marga biasanya memiliki asalusul sama dari satu garis keturunan, yang dikenal sebagai moyang bersama. Melalui perkawinan silang, kekerabatan yang semula terbatas pada keluarga inti atau keluarga semarga mengalami perluasan melampaui keluarga dan merga sendiri.

Orang Haruku tidak mengenal adanya sistem pelapisan sosial resmi, seperti pada suku bangsa Ternate. Pada mulanya masyarakat Haruku masih sederhana, serta hubungan kekeluargaan antara warga dalam satu negeri sangat erat. Pada umumnya satu negeri didiami oleh warga yang masih mempunyai hubungan geneologis. Oleh karena itu, mereka tidak merasakan adanya lapisanlapisan sosial. Walaupun demikian, dengan adanya golongan aparat pemerintahan dan warga negeri, maka masyarakat dapat digolongkan dalam dua golongan, yaitu golongan pemerintah dan warga negeri.

Karena jabatannya, pejabat pemerintah dianggap mempunyai kedudukan yang lebih tinggi dan dihormati. Selain itu, yang dianggap menempati lapisan teratas adalah guru dan tokoh agama. Sedangkan warga dianggap sebagai lapisan soaial yang kedua. Walaupun demikian, tidak terdapat perbedaan yang mencolok antara kedua golongan tersebut, misalnya dalam bentuk-bentuk rumah dan atribut-atribut lainnya. Mereka mempunyai hak dan kewajiban yang sama dalam masyarakat. Hanya karena jabatannya, para pejabat pemerintah mendapat penghormatan dengan berbagai panggilan. Pendidikan, kekayaan, keturunan, atau kesenioritasan seseorang tidak merupakan kriteria pembentukan pelapisan sosial pada suku Haruku. Golongan pejabat pemerintahan dan rakyat biasa merupakan pelapisan sosial yang tidak membawa pengaruh dalam hubungan pergaulan kedua gulongan tersebut. Tidak ada larangan tertentu untuk kedua golongan, misalnya bergaul atau melakukan perkawinan dan upacara adat lainnya (Massoweang, 2009:29).

Pelaksanaan kegiatan dan aktivitas keagamaan umat beragama pada umumnya berpusat di rumahrumah ibadah yang telah didirikan oleh pengaut dan organisasi keagamaan. Berdasarkan data BPS Maluku Tengah, jumlah penduduk kabupaten Maluku Tengah pada tahun 2012 sebanyak 375.393 jiwa terdiri dari laki-laki 189.442 jiwa, perempuan 185.951 jiwa. Dari jumlah tersebut penganut Agama Islam sebanyak 62,19\%, Protestan 36,73 $\%$, katolik $0,34 \%$, dan lainnya $0,74 \%$. Karena Penduduk di Kabupaten Maluku Tengah mayoritas beragama Islam, praktis jumlah rumah peribadatan pun terhitung paling banyak ketimbang agamaagama lain, hal ini dilihat dengan masjid 275 buah, Gereja Protestan 192 buah, Gereja Katolik 16 buah, 
sedangkan Pura terdapat 3 buah dan Vihara tidak ada.

\section{Latar Belakang Sejarah Tarian Ma'atenu}

Pada tahun 1637, pihak Pemeritah Belanda dipimpin oleh seorang Petur (penguasa) yang bernama Kombers. Dalam pertemuan yang dihadiri oleh Pemerintah Belanda bersama Raja Hatuhaha itu, terjadilah dialog yang cukup panjang, sehingga ruang pertemuan (Baileo Matasiri) yang tadinya hening menjadi tidak tenang. Di tengah pertemuan itu muncul seorang yang bernama Imam Haturesi Rua menyampaikan sanggahannya dalam sebuah syair lagu "Tuan Peture Visi Komberisasi, Tuan Muhammad jadi orang Pelauw". Syair lagu ini kalau diterjemahkan dari segi terminologi bahasa Indonesia mengandung makna bahwa Tuan Petur Van Kombers adalah orang Belanda yang mempunyai agama lain, sedangkan Pelauw pada prinsipnya beragama Islam.

Terlepas dari sanggahan di atas, Tuan Petur menyampaikan permintaan Pemerintah Belanda, antara lain:

1. Negeri-Negeri Hatuhaha seperti Pelauw, Kailolo, Kabauw, dan Rohomoni segera menyesuaikan diri dengan masyarakat Hulaliu yang sudah memeluk agama Kristen.

2. Apabila permintaan pada butir 1 (satu) di atas tidak diindahkan, maka seluruh pohon cengkeh yang ada di kawasan Hatuhaha akan dimusnahkan.

3. Hubungan ekonoi antara Negeri Hatuhaha dengan semua negeri Tetangga, terutama yang ada di Seram Selatan akan diblokade (pemutusan hubungan ekonomi).

Mendengar penjelasan yang sifatnya memaksa ini, maka Raja Hatuhaha menyampaikan sebuah permintaan kepada Tuan Petur bahwa masyarakat Hatuhaha dalam tempo waktu yang relatif singkat akan memenuhi kehendak Pemerintah Belanda, asalkan diberi waktu 3 (tiga) bulan terhitung sejak pertemuan itu.

Setelah Tuan Petur Van Kombers kembali melaporkan hasil misinya, maka Raja Hatuhaha segera memanggil tokoh-tokoh adat dan pihak-pihak yang dianggap berpengaruh untuk melaksanakan suatu pertemuan.

Pertemuan rahasia itu di laksanakan di tengah hutan di Gunung Alaka, yang oleh masyarakat dipanggil "Matasiri Lounusa”. Dalam pertemuan itu, ada beberapa hal yang dibahas, antara lain:
1. Perlu adanya mobilisasi kekuatan pertahanan dan keamanan dengan menggerakkan semua potensi masyarakat Pelauw

2. Perlu adanya persiapan kekuatan ekonomi masyarakat dengan mobilisasi seluruh potensi masyarakat Pelauw.

Ma'atenu atau disebut juga cakalele adat adalah ritual perang khas masyarakat Hatuhaha di pulau Haruku Maluku Tengah. Ritual ini dilaksanakan tiga tahun sekali, dan sudah 100 tahun lebih ritual ini dilakukan di negeri Pelauw.

Máatenu berasal dari bahasa Pelauw atau Hatuhaha Máatenu'o; terdiri dari dua suku kata yaitu kata ma'a artinya mari, dan kata tenu'o artinya mencoba atau menguji. Ma'atenu secara harfiah dapat diartikan sebagai undangan untuk menguji. Pengertian ini menunjuk pada tingkatan aktif dan keberadaan peserta Máatenu yang menguji kekebalan dan keperkasaan mereka di depan publik dengan cara memotong, mengiris dan menikam anggota tubuh mereka dengan parang atau kelewang dan benda-benda tajam lainnya.

Menguji dalam konteks historis Ma'atenu memiliki pengertian yang lebih luas, yaitu menegaskan eksistensi Islam diantara kelompokkelompok lain. Ma'atenu sebagai simbol pasukan yang dimobilasi bertujuan memperlihatkan baik kekuatan fisik maupun moral sebagai seorang muslim tulen atau benar-benar Islam (Rumahuru, Yance Zadrak, 2012: 100).

Syarat utama yang patuh dipenuhi sebagai peserta Maiatenu adalah mendapat restu atau persetujuan dari keluarga. Bagi yang belum menikah, perlu mendapat restu atau ijin dari kedua orang tuanya dan yang telah menikah perlu mendapat restu dari istrinya. Persyaratan lain adalah sebagai berikut (1) memiliki fisik dan mental baik, (2) patuh kepada orang yang memimpin, (3) rambut dicukur bersih dari kepala, (4) mengenakan busana putih seperti baju koko tanpa pengalas kaki, (5) menyiapkan pedang khusus yang diasa tajam, dan (6) menjaga perkataan dan sikap terhadap sesama. Dari beberapa hal yang disyaratkan di atas, tampak bahwa aspek moral, loyalitas dan disiplin patut dimiliki oleh seseorang peserta Ma'atenu, karena mereka dianalogikan sebagai pasukan perang atau prajurit Hatuhaha.

Di bagian awal telah disebut bahwa ritual Ma'atenu adalah ritual perang, hal ini karena beberapa alasan sebagai berikut: Pertama, Ma'atenu dikaitkan langsung dengan perjuangan orang tuatua Hatuhaha mempertahankan Islam. Kedua, peserta ma'atenu dijadikan simbol dari pasukan 
perang hatuhaha. Ketiga, peralatan ritual, yaitu parang atau pedang adalah peralatan perang tradisional yang digunakan untuk bertempur zaman dulu. Parang sebagai peralatan ritual yang juga digunakan untuk berjuang membangun hidup dengan membabat hutan dan melakukan aktivitas pertanian serta perkebunan secara tradisional sebagai basis utama sumber pendapatan kebanyakan orang pelauw. Keempat, atraksi yang ditampilkan dalam Ma'atenu seperti memotong, menikam dan mengiris tubuh sesungguhnya menunjuk pada cara-cara menaklukkan musuh. Kelima, roh kapitan atau leluhur yang hadir dalam diri peserta Mảatenu sehingga mereka $k a^{\prime} a$ atau mengalami kondisi trans dan memiliki kekebalan terhadap benda tajam ini adalah roh pemimpin kelompok perang dari masing-masing soa, yang dapat disamakan dengan komandan kelompok, bahkan panglima perang sekarang.

Ritual Ma'atenu yang menggunakan simbolsimbol perang seperti penggunaan parang atau pedang sebagai alat perang tradisional, kekebalan terhadap benda tajam yang agak mistik, bahkan peserta Ma'atenu yang diposisikan sebagai "prajurit Hatuhaha menjaga eksistensi Islam menunjuk pada konteks perang orang tua-tua Hatuhaha empat abad silam (Rumarhuru,Yance Zadrak, 2012: 107-108).

\section{Pelaksanaan Ritual Tarian Ma'atenu di Desa Pelauw}

Ma'atenu yang secara kolektif adalah milik bersama seluruh warga masyarakat Desa pelauw dimana saja berada. Máatenu yang sacral ini senantiasa dikenal oleh setiap anggota warga masyaralat Pelauw yang secara sugestif dan refleksi duduk mengenang atau menghitung kapan datang hari pelaksanaannya, dan bila harinya semakin mendekat maka warga masyarakatpun spontanitas pulang ke kampung untuk berpartisipasi untuk melaksanakan tarian tersebut. Baik mereka yang berdomisili di Desa pelauw sendiri maupun berada diluar daerahnya. Tarian Mảatenu yang akan melibatkan fisik dan mental spiritual memerlukan persiapan yang matang, untuk itu mereka diwajibkan mencukur rambut dengan maksud membersihkan diri, kemudian menggosok atau mengasah parang untuk melawan jihat dan memakai pakaian putih yang melambangkan mesucian dan kemurnian jiwa peserta Ma'atenu, hal ini merupakan persyaratan mutlak harus laki-laki yang memenuhi kriteria.

Pengertian warga masyarakat ini bukan bahwa para pendatang yang berdomisili di desa
Pelauw mempunyai hak yang sama dengan warga masyarakat pelauw yang lainnya. Hal ini terbatas pada segi keturunan, jadi yang merasa mepunyai hubungan darah baik dari keturunan secara vertikal maupun horizontal, semuanya mempunyai kapasitas yang sama terhadap pelaksanaan Tarian Máatenu.

Acara pelaksanannya diatur secara adat sesuai fungsi masing-masing perangkat adat dan peserta itu sendiri, yang semuanya saling berhubungan erat.

Secara kolektif yang bertanggung jawab terhadap pelaksanaan Tarian Maatenu adalah raja Hatuhaha yang dalam struktur pemerintahan merangkap sebagai kepala desa. Namun untuk kelancaran pelaksanaannya, dilaksanakan pendelegasian wewenang sesuai fungsi dan peraanan setiap warga.

Walaupun penanggung jawab kolektif atau keseluruhan rangkaian adalah kepala adat dalam hal ini raja, namun untuk kelancaran dari rangkaian acara ini terdapat pembagian tugas sesuai fungsi dan peranan masing-masing soa (marga). Penanggung jawab sebagai berikut:

1. Kepala adat (raja) sebagai penanggung jawab kolektif mempunyai batas wewenang sebagai berikut:

- Mengumumkan waktu pelaksanaan sesuai keputusan Saniri Negeri (Lembaga Tertinggi Negeri).

- Memberikan mandat kepada setiap kepala marga untuk mengkonsolidasikan marganya.

2. Kepala rumah atau sebagai seorang yang dituakan pada suatu marga mempunyai batas wewenang sebagai berikut:

- Mengadakan rapat konsolidasi antara seluruh warga rumah tua tentang pelaksanaan Tarian Ma’atenu.

- Menentukan personil untuk memimpin warganya yang akan ikut upacara dan yang akan bergabung dalam 2 (dua) kelompok besar yaitu kelompok lima yang disebut Latu Rima atau 5 (lima) Raja dan kelompok Urisyiwa atau kepala 9 (sembilan) kelompok, masing-masing sub kelompok Waelurui dan sub kelompok Waelapia. Untuk kelengkapan upacara ini setiap kelompok membawakan makanan yang dikumpulkan dirumah adat yang disebut Asari (Baileo), kemudian secara bersama-sama pula mereka membuat 
tempat makanan pula.

Para peserta Ma'atenu tempat pelaksanaannya yang berpisah sesuai dengan rute perjalanan masingmasing peserta. Secara umum dapat kita ikuti dalam tabel 1.

Tabel 1: Pembagian Masing-Masing Peserta Sesuai Dengan Rute Perjalanan

\begin{tabular}{llccc}
\hline No & Peserta & Sektor Timur & Sektor Selatan & Sektor Barat \\
\hline 1 & Latuconsina & - & - & Sektor Barat \\
2 & Latupona & - & - & Sektor Barat \\
3 & Latuamury & - & - & Sektor Barat \\
4 & Sahubawa & - & - & Sektor Barat \\
5 & Talaohu & - & Sektor Barat \\
6 & Salampessy & - & Sektor Selatan & - \\
7 & Angkotasan & - & Sektor Selatan & - \\
8 & Tuankotta & - & Sektor Selatan & - \\
9 & Tuakia & - & Sektor Selatan & - \\
10 & Tualepe & - & Sektor Selatan & - \\
11 & Tuni & Sektor Timur & - & - \\
12 & Tualeka & Sektor Timur & - & - \\
13 & Tuahenka & Sektor Timur & - & - \\
14 & Tuasikal & Sektor Timur & - & - \\
\hline
\end{tabular}

Untuk membedakan masing-masing sektor, maka setiap sektor mempunyai nama sebagai berikut:

\section{Sektor Barat disebut Latu Rima}

Peserta sektor ini terdiri dari 5 marga. Disebut Latu Rima karena sebagian besar yang yang mengikuti sektor ini bermarga Latu (Latuconsina, Latupono, Latuamury), peserta soa Talouhu berkumpul di Rumanai Lesirohi bersama peserta soa Sahubawa. Peserta yang berkumpul di rumah Ela atau Rumanai Latuconsina segra bergabung dengan peserta Soa Tolaohu dan peserta Soa Sahubawa di Rumanai Lesirohi milik Soa Sahubawa. Setelah dua grup ini berkumpul, maka tiba pada menjeput atau melamai kapitang oleh 2 (dua) petugas dari Soa Tuelepe (Rumanai Pau).

Kapitan yang akan memimpin Laturima (Patasiwa) ini, sebelum berangkat terlebih dahulu harus mohon restu sekaligus laporan kepada Juru Pusaka Salampessy dengan menjabat tangan Upu Sisyi Rumanai Sampale yang saat itu duduk bersila ditempatnya.

Kemudian sang Kapitan Pau Tualepe dikawal kedua penjemput menuju Rumanau Lesirohi, disana telah berkonsentrasi Laturima atau Matasiri menunggu kedatangan sang Kapitan. Saat itu berkumpul pada pukul 09.00 WIT dan dilakukan upacara doa selamatan dipimpin oleh Sesepu atau Juru Pusaka dari Sahubawa, untuk memberikan ketenangan dan percaya diri bagi para peserta Ma'atenu untuk menuju makam keramat Matasiri.

Di lokasi makam keramat Matasiri, mereka berkumpul dihalaman sebuah Baileo yang bernama Matasiri yaitu Balairung asal Uli Hatuhaha Lou Nusa Amarima. Lokasi bekas pemukiman lama yang terdapat rumah adat model daerah-daerah yang terpelihara dengan baik itu, para peserta membersihkan dan beristirahat sejenak setelah itu mereka makan siang bersama. Kemudian dilakukan upacara selamatan dengan mohon doa restu dan mohon kekuatan lahir dan bathin kehadirat Allah swt untuk mengalahkan semua kekuatan bathil.

Disini sang Kapitan atau Mảahala Lahat telah memperoleh kekuatan yang tersimpan dalam kain lahat yang merupakan kekuatan untuk seluruh kelompok Latu Rima yang dipimpinnya. Setelah itu mereka mandi di sungai untuk membersihkan diri, setelah mandi bersih, satu persatu dimandikan oleh Ma'ahala Lahat untuk selanjutnya diuji kekebalan fisiknya oleh Ma'ateru Ame dengan pedang tajam dan selanjutnya pulang menuju Pekarangan Masjid (Taeamen).

\section{Sektor Selatan disebut Urato Roho Rhima}

Disebut Urato Roho Rhima, karena pesertanya terdiri dari 5 marga yang medan sektirnya terdiri dari daerah yang bergunung. Sektor ini sering disebut Waelurui, karena terminal akhir dari sektor ini berpusat di hulu sungai Wae Marikee. Sebelum berangkat ke terminal sektor, mereka (peserta Ma'atenu) berkumpul di rumah clan Tualepe. Para peserta Waelurui berkumpul pada pukul 09.00 WIT dan kemudian dilakukan upacara doa selamatan yang dipimpin oleh sesepuh rumah 
adat klan Tualepe, sedangkan Kepala Adat (Raja) memberikan minuman berupa air kepada para peserta setelah dibacakan doa dan shalawat Nabi untuk memberikan ketenangan dan percaya diri bagi para peserta Máatenu. Di rumah adat clan Tualepe sudah ada Ma'ahala Lahat dan Ma'ataru Amen yang akan memimpin kelompok yang menuju Waelurui, petugas protokol dari Soa Tualepe dan Mảahala Lahat telah siap mengendong kain merah atau kainnya dan ditutup tudung yang berarti kain lahat tersebut belum terisi penuh dengan kekuatan magis, ma;ahala berarti menggendong atau memikul sedangkan Lahat berarti liang kubur, juga berarti kandungan ibu yang suci dan penuh rahasia gaib dan zat pencipta alam semesta.

Di lokasi keramat Waelurui, mereka berkumpul di halaman sebuah keramat yang disebut Te'put di hulu sungai Air Marakee dan mereka membersihkan daerah sekitarnya, kemudian dilakukan upacara selamatan yang dipimpin oleh Ma'ahala Lahat yang diawali dengan pembakaran damar. Pembakaran damar menyebarkan aroma kemenyan ke alam bebas menambah kenikmatan udara segar dan membangkitkan tenaga dan daya menjelajah hutan belantara, bertujuan untuk memohon doa dan kekuatan lahir batin dari Allah swt untuk melawan semua kekuatan yang bathil.

Disini Ma'ahala Lahat memperoleh kekuatan yang tersimpan dalam kain lahat yang merupakan kekuatan untuk seluruh kelompok Waelurui yang dipimpinnya. Setelah itu mereka makan siang bersama dengan sistem patita, kemudian mandi bersih satu persatu dimandikan oleh Maahala Lahat, untuk selanjutnya diuji kekebalan fisiknya oleh Ma'ataru Ame dengan pedang tajam, dan selanjutnya pulang menuju pekarangan Masjid dipimpin oleh Ma’ahala Lahat dan Ma’ataru Ame.

\section{Sektor Timur disebut Tuni Mahua Waelapia}

Peserta sektor ini terdiri dari 4 (empat) marga. Sektor ini disebut Tuni Mahua Waelapia karena terjadinya perpaduan unsur Tuni Mahua sedangkan Waelapia diambil dari terminal akhir yang terletak di dusun Waelapia.

Sebelum berangkat, sektor ini berkumpul di rumah adat clan Tualeka, para peserta berkumpul tepat pukul 09.00 WBTI, kemudian dilakukan upacara selamatan yang dipimpin oleh Sesepuh rumah adat clan Tualeka, sedangkan Kepada Adat (Raja) memberikan minuman berupa air kepada para peserta setelah dibacakan doa dan shalawat Nabi untuk memberikan kekuatan dan percaya diri bagi peserta Mảatenu.
Di rumah clan Tualeka, kelompok Tuni Mahua Waelapia menunggu kedatangan Ma'ahala Lahat dan Maateru Ame yang akan memimpin kelompok menuju makam keramat Tuni Mahua Waelapia. Petugas protokol dari clan Tualepe segera menuju rumah adat clan Tualepe untuk menjemput Ma’ahala lahat. Ma'ahala berarti menggendong atau memikul, sedangkan Lahat berarti liang kubur, juga berarti kandungan ibu yang suci dan penuh rahasia dari sang pencipta alam semesta.

Dilokasi keramat Waelapia, merekaberkumpul di halaman sebuah keramat yang terletak di kaki Air Waelapia dan membersihkan daerah sekitarnya, kemudian dilaksanakan upacara selamatan dengan memohon kekuatan lahir dan batin kehadirat Allah untuk mengalahkan semua kekuatan yang bathil.

Disinilah ma’ahala lahat memperoleh kekuatan yang tersimpan dalam kain lahat yang merupakan kekuatan untuk seluruh kelompok Tuni Mahua Waelapia yang dipimpinnya. Setelah itu mereka makan siang, kemudian mandi di sungai Waelapia untuk membersihkan diri. Sewaktu mandi, satu persatu dimandikan oleh Ma'ahala Lahat selanjutnya diuji kekebalan fisiknya oleh Ma'ataru Ame dengan pedang tajam, dan selanjutnya pulang menuju pekarangan Masjid (Tauwamen).

Usai shalat Ashar, peserta mulai memasuki medan laga di depan Masjid, disitu peserta (dibagi 3 kelompok) unjuk kebolehan secara bergantian. Selagi berlaga itu, mereka di dampingi oleh Mảateru Ame atau pembimbing.

Selain acara pembuka, beduk Masjid di tabuh dilanjutkan dengan pemukulan rebana, tiba dan toto buang setelah itu atraksi baku potong di laksanakan, kelawang, parang, golok yang rata-rata sepanjang 30-75 $\mathrm{cm}$ berkelebatan memotong leher, mengiris lidah atau memotong tubuh. Benda tajam itu diiriskan pada tubuh sendiri dan ketubuh adik, ponakan atau kerabat.

Ma’atenu berhenti laga, mereka disambut sekitar 30 ibu-ibu, yang mengenakan kebaya warna biru dan bersarung batik di pintu Baileo (Balai Desa). Kain salele merah yang dipegang dikalungkan satu persatu ke leher peserta "Pengalungan itu ibarat menyambut kedatangan para pahlawan yang menang di medan perang".

Pelaksanaan Tarian Mảatenu sebagaimana penulis uraikan pada bagian terdahulu bahwa sangat erat dengan misi kristenisasi yang dibawah Pemerintahan Belanda. Team atau ekspedisi kristenisasi tersebut di pimpin oleh Tuan Peter van Kombers, yang tiba di Desa Pelauw pada 
bulan Rabiul Awal tahun 1637 Masehi. Kemudian Tuan Peter Van Kombers datang untuk menagih kesepakatan bersama yang diambil di pertemuan Baileo Matasiri. Kedatangan Tuan Peter Van Kombers terjadi pada bulan Jumaidil Awal.

Dan kedatangan ini oleh masyarakat setempat dengan upacara Ma'atenu yang biasanya dilaksanakan pada hari kamis tiga tahun sekali. Tuan Peter van Kombers tiba di Pelauw pada hari rabu pukul 16.00 WIT, dan sesuai rencana mengkristenkan masyarakat secara serempak dan spontanitas, loyalitas dan partisipasi mengkonsolidasikan berbagai kekuatan untuk potensi keamanan dan kemampuan masyarakat Pelauw dari segi pertahanan (Máatenu) maupun petahanan ekonomi kepada ekspedisi Peter dengan sendirinya akan mengalami kegagalan total untuk mengkristenkan masyarakat Pelauw. Permintaan pemerintah Belanda mengalami kegagalan itu dimeriahkan oleh masyarakat Pelauw dalam bentuk Tarian Máatenu (Azis Tuasikal, wawancara, senin 16 juni 2014).

\section{Tahapan-Tahapan Pelaksanaan Ma'atenu}

Terdapat pentahapan ritual yang patut dilihat dalam perspektif bahwa antara satu tahap ke tahap lain memiliki hubungan yang membentuk satu keutuhan. Tahap-tahap dalam ritual Máatenu adalah sebagai berikut:

1. peserta berkumpul di rumah soa kecil atau anak soa.

2. Peserta ke rumah soa besar atau soa induk,

3. Peserta beberapa soa digabung di salah satu rumah soa membentuk satu kelompok atau sektor sesuai arah mata angin (Timur, Barat dan Selatan) dan keramat yang dituju

4. Peserta ke keramat atau jazirah makam leluhur

5. Peserta ke tempat mandi atau pembersihan dan tempat istirahat menunggu waktu kembali ke kampung,

6. Peserta ke arena atraksi di halaman masjid dan baileu, dan

7. Peserta masuk ke baileu.

Umumnya halaman masjid dan baileu disebut sebagai tempat acara Ma'atenu, tetapi kiranya menjadi jelas setelah melihat tempat dan pentahapan ritual tersebut diatas. Halaman masjid dan baileu merupakan arena terakhir bagi peserta Ma’atenu melakukan atraksi memotong, mengiris dan menikam anggota tubuhnya. Ritual Máatenu diakhiri dengan masing-masing peserta masuk ke baileu dan disambut oleh sejumlah ibu-ibu yang mengalungkan kain pada leher peserta.

Malam hari sebelum diadakan ritual, umumnya peserta sudah berkumpul pada rumah soa kecil masing-masing. Tujuan berkumpul adalah:

1. Untuk mendapat penjelasan tentang hakekat Ma'atenu dan hal-hal yang patut diperhatikan dalam pelaksanaan Mảatenu, oleh seorang yang dituakan di soa, dan

2. Untuk bersama-sama dengan anggota marga atau soa yang lain keesokan harinya menjadi satu kelompok menuju rumah tua atau rumah soa besar dari soa bersangkutan.

Semu peserta yang tidur di rumah soa kecil pagi-pagi harus bangun untuk sarapan, mandi, mengenakan pakaian putih, dan bersiap-siap menuju ke rumah tua. Ada juga sebahagian peserta tidur di rumahnya sendiri, tetapi jam 06.00 sampai 06.30 sudah bergabung di rumah soa kecil, untuk sama-sama menuju ke rumah soa besar. Mereka yang tidur di rumah sendiri adalah warga soa yang sudah pernah mengikuti Ma'atenu, sedangkan bagi peserta baru wajib tidur di rumah soa kecil.

Jam 07.00 peserta dari masing-masing rumah soa kecil telah menuju rumah soa besar, waktu peserta Ma'atenu keluar dari rumah soa kecil menuju rumah soa besar atau rumah tua, peserta sudah mulai menari-nari dengan kalewang atau parang yang dibawahnya, sambil menunjukkan atraksiatraksi singkat, mengiris badan atau menikam dan memotong diri sendiri dengan benda-benda tajam yang dibawahnya. Aksi ini bagi orang yang belum biasa menyaksikannya cukup mengerikan, karena peralatan yang digunakan semuanya diasa tajam, dan mereka memotong atau menikam diri sendiri secara sungguh-sungguh tetapi tidak luka dan tidak mengeluarkan darah. Bila ternyata ada diantara mereka yang luka atau berdarah maka dianggap bahwa orang itu tidak bersih. Tidak bersih mengandung pengertian bahwa yang bersangkutan masih memiliki kesalahan tertentu, dan belum menyelesaikannya saat hendak mengikuti mảatena. Luka atau berdarah saat mengikuti Mảatenu juga bisa disebabkan karena yang bersangkutan tidak mendapat restu dari orang tua atau istri bagi yang sudah menikah.

Di rumah tua atau rumah soa besar, para peserta diterima oleh beberapa orang tua, dipersilahkan masuk satu persatu dan duduk membentuk lingkaran memenuhi ruangan yang tersedia untuk menghadap kepada soa. Menurut Bapak Taher Angkotasan, bahwa setiap peserta ritual 
yang masuk ke rumah soa sudah diliputi semangat dan kesiapan mental layaknya seorang prajurit sejati yang siap memasuki medan perang (Wawancara Taher Angkotasan, 63 tahun, 17 Juni 2014).

Selain kepala soa, hadir juga beberapa orang tua-tua dari soa tersebut. Di tengah-tengah lingkarang peserta dan orang tua-tua, terdapat satu mangkuk putih berisi air yang dialas dengan piring putih. Setelah semua peserta berkumpul, seorang tua memberi pengarahan singkat dalam bahasa Pelauw, memimpin doa dan bacaan Salawat Nabi, diikuti oleh seluruh peserta. Pembacaan Salawat Nabi dimaksudkan untuk memberikan ketenangan dan kekuatan tersendiri bagi para peserta. Setelah membaca salawat Nabi, air dalam mangkuk dipercik di kepala semua peserta dalam ruangan tersebut.

Pembacaan Salawat Nabi (doa) dan pemercikkan air oleh seorang tua di rumah soa besar kepada para peserta Máatenu dapat disebut sebagai praktik simbolis dari ajaran adat dan agama yang menggambarkan bahwa dialektika atau kontekstualisasi adat dan agama sudah lama terjadi di pelauw. Dalam hal ini ajaran islam dan adat atau budaya lokal tidak sekedar saling mengambil atau mengadopsi dan menolak atau melakukan pemurnian satu terhadap yang lain, tetapi ada proses adaptasi secara imbang dengan melihat hakekat dari setiap ajaran dan nilai yang diperaktekkan untuk menemukan otensitas beragama dalam budaya.

Dari rumah soa besar peserta Ma'atenu yang telah dibagi menjadi tiga sektor atau bagian tersebut berkumpul bersama dalam satu rumah soa, sebelum menuju ke keramat. Berkumpul secara bersama ini dimaksudkan untuk mengkonsulidasi kekuatan dan menunggu datangnya Ma'ahala Lahat dan Ma'ataru Ame dari marga Tualepe. Kecuali sektor Timur, yang di dalamnya anak-anak dan keturunan soa Tualepe juga ikut, disana sudah ada Ma'ahala Lahat dan Ma'ataru Ame.

Setelah gabungan soa-soa berkumpul bersama sekitar jam 09.30, masing-masing kelompok diberangkatkan ke keramat, berjalan setengah berlari sambil menunjukkan atraksinya. Kelompok yang diberangkatkan pertama adalah kelompok Latu Rima disusul oleh kelompok Waelurui atau Urato Robo Rhima dan kelompok Tuni Mahua Waelapia. Jumlah anggota masing-masing kelompok bervariasi, berkisar 250-300 orang perkelompok.

Kelompok atau sektor Barat terdiri dari marga: Latuconsina, Latupono, Latuamury, Sahubawa dan Talaohu. Kelompok tidak berkumpul sekaligus pada satu tempat, tetapi pada dua tempat yang berbeda kemudian bergabung pada satu tempat sebelum ke keramat. Marga latuconsina, Latupono dan latuamury berkumpul di rumah Ela atau rumah nai Latuconsia sedangkan marga Sahubawa dan Talaohu berkumpul di rumah nai Lasirohi, milik soa Sahubawa. Marga atau sao Latuconsia, Latupono dan Latuamury kemudian bergabung dengan Sahubawa dan Talaohu di rumah nai Lasirohi. Kelompok atau sektor timur terdiri dari marga: Tualeka, Tuni, Tuahena dan Tuasikal. Seluruh peserta kelompok ini berkumpul pada rumah adat marga Tualeka. Kelompok Timur dan Barat mengambil Ma'ahala Lahat dan Máataru Ame dari marga Tualepe untuk memimpin mereka.

Sekitar jam 12 siang, peserta Ma'atenu sudah tiba di keramat. Di keramat mereka membersihkan lokasi keramat dan melakukan doa bersama. Doa diawali dengan membakar damar di keramat dan dipimpin oleh Ma'ahala Lahat. Walau tidak ada sesaji seperti pada sejumlah ritual-ritual lainnya, tetapi pembakaran damar dapat dimengerti sebagai bentuk pemujaan kepada kuasa paling besar atau kuasa tertinggi dan penghormatan kepada leluhur yang telah menjaga dan melindungi mereka. Setelah doa selamatan, peserta menyantap makanan yang telah disediakan oleh sejumlah ibu-ibu. Sehabis makan bersama di keramat, para peserta menuju kali dekat dengan keramat untuk mendi dan selanjutnya beristirahat di sana sampai waktu yang telah ditentukan untuk kembali ke kampung. Peserta Máatenu mandi di kali setelah mereka kembali dari keramat dan akan menuju ke kampung dapat dipahami sebagai proses pembersihan diri dan kesiapan mengemban tugas sebagai "prajurit Hatuhaha”.

Dalam perjalanan kembali ke kampung dan masuk arena atraksi di halaman masjid dan bailen, semua peserta mengalami kemasukan roh kapitan atau leluhur yang disebut $k a^{\prime} a$, yakni kondisi trans dan peserta tampak memiliki kekebalan terhadap benda-benda tajam. Beliau juga mengatakan bahwa anggota keluarga yang mengantar anak atau saudara atau suami mereka mengikuti Mảatenu, menemukan bahwa terdapat kebanggaan tersendiri bagi mereka mengikuti Máatenu, bila melihat mereka ka'a, yang berarti bahwa mereka berhasil mendapat perhatian dari para leluhur atau kapitan mereka. Relasi dengan leluhur begitu penting karena leluhur dianggap dapat memedaiasi mereka dengan kuasa yang paling besar atau dapat disebut Sang pencipta. Apabila para pengantar melihat saudara mereka yang menjadi peserta Ma'atenu belum ka’a, segera dipancing dengan cara bersuara keras atau 
menar-nari mencari perhatian mereka. Beberapa informan yang terlibat dalam ritual dengan Maatenu menuturkan bahwa bila mereka berjumpa anggota keluarganya, secara serentak mereka mengalami kemasukan roh atau ka'a. Apabila kalau mereka melihat ibu atau saudara-saudara perempuan atau istri berada di sekitar mereka.

\section{- Kelompok tifa dan rebana}

Pelaksanaan Mảatenu diramaikan oleh satu grup musik tersendiri terdiri dari beberapa orang lak-laki dan perempuan, mereka memainkan tifa dan rebana sambil menyanyikan syair-syair atau lani (bahasa Pelauw) untuk memberikan semangat kepada para peserta ritual. Ada dua lani (syair) yang dinyanyikan berulang-ulang;

\section{Lani 01.}

Titaheu-heu e Titaheu-heu e

Tura Lani rua

Mantura lanai irua

\section{Lani 02.}

Upu tua poe yasela

Isi ana hutu telu

Bonbonua máatita urat

Lani-lani ini sesungguhnya merupakan pujian kepada pasukan perang Hatuhaha, yang disimbolkan dengan memberi semangat kepada Upu Rihia (Kepala Kapitan Hatuhaha) dan Upu Matawoku (Wakil Kapitan Hatuhaha).

Lani-lani ini waktu dinyanyikan ibu-ibu dan para pengantar juga turut bernyanyi dengan suara keras atau agak berteriak. Pada waktu lani-lani tersebut dinyanyikan keras, para peserta Máatenu pun tampak semakin bersemangat, histeris dan setiap peserta mendapat kemasukan roh leluhur mereka atau ka'a. Lani-lani di atas memiliki makna mengingatkan para peserta Máatenu kepada kegagahan leluhur mereka mempertahankan identitas agama dan menyiarkan agama Islam, serta bertempur melawan musuh-musuh mereka. Dalam perspektif ini terlihat bahwa kelompok musik (tifa dan rebana) berperan memberi dukungan mental dan semangat perjuangan kepada para peserta Ma'atenu.

\section{- Peran Perempuan}

Ritual Ma’atenu sudah harus berakhir sebelum jam 16.00 wit, jadi seluruh peserta sudah masuk di halaman masjid dan baileu sebelum waktu ini. Untuk itu sekalipun menempuh perjalanan panjang (sekitar 10 s.d $15 \mathrm{Km} \mathrm{PP)} \mathrm{dan} \mathrm{melelahkan} \mathrm{tetapi}$ sesuai waktu yang ditentukan, semua pasukan sudah berada di halaman masjid dan baileu untuk mempertunjukkan kekebalan masing-masing terhadap benda-benda tajam. Atraksi memotong, mengiris, menikam badan. dan anggota tubuh dengan parang, pisau dan benda-benda tajam lainnya berlangsung di halaman masjid dan baileu sekitar 1 jam s.d 1,5 jam.

Mengahiri acara Ma'atenu, semua peserta teratur satu demi satu masuk ke baileu. Tedapat 30 ibu-ibu setengah baya dengan busana kain dan kebaya berdiridi pintu masuk baileu bagian Timur menyambut setiap peserta Ma'atenu dan mengalunkan kain ke leher mereka. Pengalungan kain tersebut kepada peserta Ma'atenu, sekaligus menandai berakhirnya ritual ini adalah suatu akta simbolik, bermakna pemulihan dan syukur. Peran seorang ibu atau seorang istri sudah tampak sejak persiapan peserta. Sebagaimana disebut sebelumnya bahwa laki-laki yang mengikuti Máatenu perlu mendapat restu dari ibu atau istri mereka. Sama seperti pada awal hendak mengikuti Ma'atenu membutuhkan restu ibu atau istri maka dalam mengakhiri ritual ini sejumlah ibu-ibu yang hadir di baileu merupakan representasi semua oang perempuan di Pelauw yang menerima kedatangan prajurit Hatuhaha yang tidak lain adalah anakanak dan suami mereka dengan ungkapan syukur, karena telah menunaikan tugasnya dengan baik dan dilindungi oleh Allah Taalah.

Mengingat peserta Máatenu selama kurang lebih 10 jam sejak pukul 06.00 s.d 15.30 waktu setempat telah mengalami satu proses pengujian diri melalui pelaksanaan Ma'atenu dan mereka diliputi oleh kekuatan roh leluhur yang berarti bahwa mereka tidak menyadari secara penuh apa yang terjadi pada diri mereka sama seperti kondisi normal, maka kondisi mereka perlu dipulihkan.

Pengalungan kain oleh ibu-ibu adalah untuk memulihkan kondisi para peserta dari kemasukan oleh leluhur menjadi normal kembali. Hal ini mengandung pengertian bahwa perempuan menjadi sumber harmoni. Fenomena ini menunjukkan bahwa perempuan menjadi sumber energi yang ampuh bagi laki-laki Hatuhaha, yang berarti juga bahwa pengabaian terhadap perempuan berdampak pada konflik atau kehancuran (Rumahuru, Yance Zadrak, 2012: 116-117).

\section{Makna Ritual Ma'atenu}

Ritual Máatenu di Pelauw memiliki makna yang penting bagi kehidupan komunitas setempat. Mengingat ritual ini dikonstruksi dalam kelompokkelompok masyarakat yang telah memeluk agama Islam, maka makna ritual Máatenu dapat dipahami dengan melihat hubungan antara agama (Islam) dan 
adat yang membentuk manusia Hatuhaha, secara khusus di negeri Pelauw.

Memperhatikan konteks kemunculan ritual Máatenu dan pelaksanaannya saat ini dengan simbol-simbol yang dimiliki, maka beberapa makna ritual dapat disebut sebagai berikut:

1. Makna Religius, yakni ketaatan dan penyembahan kepada kuasa terting(Allah Taala), yang berarti pula menjaga eksistensi agama yang telah dianut;

2. Makna Adatis, yakni penghormatan kepada leluhur, sekaligus menjaga relasi baik dengan leluhur atau satu sama lain yang disebut dengan maningkamu. Implementasi dari penghormatan kepada leluhur adalah melaksanakan tuntutan adat secara baik;

3. Makna sosial, yakni membangun solidaritas kelompok atau yang dikenal dengan istilah lokal setempat ikatan maningkamu, yakni ikatan hubungan persaudaraan. Solidaritas kelompok tampak melalui saling tolong menolong, saling menghormati dan kerja sama. Makna ritual dan nilai-nilai yang disebut ini merupakan kekuatan yang menjadi modal sosial bagi semua orang Hatuhaha Saat ini untuk membangun hidup dan mengalami perubahan.

\section{PENUTUP}

Awal timbulnya Tarian Ma'atenu adalah karena adanya paksaan dari pihak Belanda untuk mengkristenkan masyarakat Pelauw, serta berfungsi sebagai persiapan strategi perjuangan masyarakat untuk melawan Belanda. Pelaksanaan Upacara tarian Máatenu dilaksanakan satu kali dalam tiga tahun, dan makna yang terkandung dalam upacara ini adalah makna Agama, makna adat dan makna sosial.

Dengan melihat berbagai permasalahan yang terjadi di dalam penelitian lapangan, maka diharapkan: Kepada masyarakat dihimbau agar Tarian Mảatenu perlu dilestarikan dan dipertahankan keutuhannya. Kepada generasi tua dihimbau agar segala sesuatu yang bertalian dengan Tarian Ma'atenu perlu diwarisi kepada generasi berikutnya. Kepada pihak Pemerintah, tokoh adat, dan tokoh Agama dapat menghimbau masyarakat untuk melakukan tradisi kesenian yang bernuansa Islam untuk dilestarikan dan dilaksanakan kepada generasi berikutnya.

\section{UCAPAN TERIMA KASIH}

Terima kasih penulis haturkan kepada pemerhati budaya yang telah eksis dalam mengembangkan dan melestarikan budaya-budaya lokal yang berkembang di masyarakat khususnya tarian. Salah satu tarian tersebut adalah Tarian Máatenu di Desa Pelauw Kecamatan Pulau Haruku Kabupaten Maluku Tengah. Terimakasi kepada seluruh informan peneliti yang telah memberikan informasi dan data terkait tarian ini. Kepada Tim Jurnal Al Qalam terimakasi penulis haturkan atas terbitnya tulisan ini.

\section{DAFTAR PUSTAKA}

Abu Muslim, 2013. Artikulasi Religi sajak-sajak Basudara di Maluku. Jurnal Al Qalam. Volume 19 Nomor 2 November 2013.

Atho Mudzhar, 2009. Pengembangan Jaringan Riset dalam rangka penguatan peran Agama dalam Pembangunan Nasional. Departemen Agama Badan Litbang dan Diklat.

BPS. Kabupaten Maluku Tengah dalam Angka 2013

Dinas Kebudayaan dan Kepariwisataan Provinsi Sulawesi Selatan, 2012. Mozaik Kepurbakalaan Sulawesi Selatan. Makassar: Culture and Tourism Office of South Sulawesi.

Massoweang, Abd. Kadir dkk, 2009, Inventarisasi, Pemetaan, dan Digitalisasi Naskah Klasik. Laporan Penelitian Balai Litbang Agama Makassar: Makassar

Mustafa, Muhammad Sadli, 2013, Lectures In Harmony: Potret Khazanah Islam Nusantara. Bunga Rampai Penelitian Lektur, Makassar: Lephas.

Ralahalu, Karel Albert, 2012, Berlayar Dalam Ombak, Berkarya Bagi Negeri, Pemikiran Anak Negeri Untuk Maluku, Ralahalu Institut, Ambon-Maluku.

Rohidi, T.R., 2000. Kesenian dalam Pendekatan Kebudayaan, Bandung:STSI Bandung.

Rumahuru, Y. Zadrak. 2012, Islam Syariah dan Islam Adat: Konstruksi Identitas Keagamaan dan Perubahan Sosial di Kalangan Komunitas Muslim Hatuhaha di Negeri Pelauw: Cetakan Pertama-Desember, Kementerian Agama RI

Sedyawati, E.1981. Pertumbuhan Seni Pertunjukan. Jakarta: Sinar Harapan.

Soedarsono, R.M. 1992. Pengantar Apresisi Seni. Jakarta: Balai Pustaka

Sulistyowati, B. 1989. Fungsi Bedhaya Anglir Mendung Sebagai Legitimasi Kekuasaan di Mangkunegaran. Skripsi untuk Gelar Sarjana Antropologi. Jakarta: Universitas Indonesia. 